\title{
Res Nullius vs. Res Communis in Matters of Communal Lands of Smallholder Farmers in Ethiopia
}

Daniel Behailu Gebreamanuel* and Getiso Detamo Mekebo**

\begin{abstract}
Communal land is among the key factors in the enhancement of rural livelihood because it enables mixed farming practices. Although communal lands are prime sources of livelihood in rural farming communities, empirical evidence shows gaps in their legal recognition and protection in Ethiopia. There are encroachments which include government intrusion, informal land sale, distribution, and handing out land (selling communal land in informal markets) as Kebele's contribution for development projects. These factors entrench poverty by sidelining the rural poor at the grassroots whose life is anchored on these lands. These problems also entail violation of human rights of the rural population. This article interrogates the misconception which tends to consider communal lands (customary land tenure) as res nullius (ownerless property) while such lands are in fact res communis (community property). The article uses the Hadiya Zone as a case study. It is argued that there is the need for the effective implementation and amendment of land laws which require political will to ensure tenure security of communal lands thereby securing and diversifying the livelihoods of poor smallholder rural farmers and ensuring human rights.
\end{abstract}

\section{Key terms}

Communal lands $\cdot$ Livestock $\cdot$ Poverty $\cdot$ Livelihoods $\cdot$ Rural Poor $\cdot$ Tenure security

DOI http://dx.doi.org/10.4314/mlr.v12i1.4

Received: 13 February 2018

Accepted: 28 September 2018

This article is licensed under a Creative Commons Attribution-NonCommercialNoDerivs (CC BY-NC-ND)

\footnotetext{
* Daniel Behailu Gebreamanuel (PhD), Asst. professor of law, Hawassa University, Email: <danielbehailu@yahoo.com>

** Getiso Detamo Mekebo (LL.M). The coauthor has collected the data for this article and drafted sections 6 and 7 of the article. Email: <getdetamo@gmail.com>.
} 


\section{Introduction}

In Ethiopia, communal land rights and attendant matters are largely discussed in terms of pastoral society or semi-pastoral society. However there are communal lands among the smallholder farmers as well. Hadiya Zone (in SNNPRS) is taken for the purpose of case study so that it can give insight to the problems discussed in this article. There are gaps in the legal regime in the protection of communal land rights thereby undermining livelihood diversification. Little attention is given to protect communal lands among smallholder farmers, and the steady erosion of customary rules and institutions call for serious reform.

Land is among the most important assets for the rural population. ${ }^{1}$ It is vital source of livelihood and can be part of cultural and social identities. ${ }^{2}$ Especially, it is the sole source of livelihood for the overwhelming majority of the rural poor and is the most crucial medium to alleviate rural poverty. ${ }^{3}$ According to World Bank and IFAD (International Fund for Agricultural Development) report, out of the total population of third world countries, $75 \%$ are rural dwellers. ${ }^{4}$ In Ethiopia, more than $83 \%$ of the total population are rural dwellers. ${ }^{5}$ Land in Ethiopia, for rural residents, is more than source of livelihood. ${ }^{6}$ Landlessness can put one's life into jeopardy and erode social identity (personhoods). ${ }^{7}$

${ }^{1}$ Desalegn Rahmato (2008), The Peasant and The State: Studies in Agrarian Change in Ethiopia 1950s - 2000s (Create Space Independent Publishing Platform) 1-15; Berhanu Abegaz (2004), 'Escaping Ethiopia's Poverty Trap: The Case for a Second Agrarian Reform' Journal of Modern African Studies, No.42; John W. Bruce and Others (2006), Land Law Reform, Achieving Development Policy Objectives (The International Bank for Reconstruction and Development / The World Bank) 1-5.

${ }^{2}$ Rachael S. Knight (2006), 'Statutory Recognition of Customary Land Rights in Africa: An Investigation into Best Practices for Law Making and Implementation' (FAO 2010) 1-3.

${ }^{3}$ Muradu A. Srur, (2015) State Policy and Law in Relation to Land Alienation in Ethiopia (University of Warwick, School of Law, PhD Thesis 2014) 1-3; Muradu A. Srur, 'Reforming Expropriation Law of Ethiopia', Mizan Law Review, Vol. 9, No.2, 301.

42017 World Bank Poverty Assessment, infra note, 41; see also, Klauis Dieninger (2011) and others, 'Rising Global Interest in Farm Land: Can it yield Sustainable and Equitable Benefits? (The World Bank) 1-7.

${ }^{5}$ Daniel Behailu, (2015) Transfer of Land Rights in Ethiopia: Towards Sustainable Policy Frame Work (Eleven International Publishing); Richard Pankhurst (1966), State and Land in Ethiopian History, Preface (Central Printing Press) 1-10.

${ }^{6}$ Daniel Behailu Geberamanuel and Gemmeda Amelo Gurero, (2017), 'The Enigma of Informal Rural Land Deals In Ethiopia: Evidence from Peri-urban Areas of Hawassa City,' Haramaya Law Review 6, 43-66

${ }^{7}$ Daniel W. Ambaye, (2012), 'Land Rights in Ethiopia: Ownership, Equity, and Liberty in Land Use Rights', FIG Working Week Rome, Italy, 6-10, pp. 1-5. 
The main concern on land rights in Ethiopia relates to tenure insecurity and productivity-related problems. As a result, the majority of Ethiopia's rural poor live below the poverty line. ${ }^{8}$ This is due to the enduring legacy of land policy which presupposes natural resource control to maintain political power. ${ }^{9}$ Some of the manifestations of poor land policies of all successive regimes are landlordism, acute exploitation, land fragmentation, resource degradation and abject poverty. ${ }^{10}$ According to Sen, Pogge and others, persistence of severe poverty amounts to violation of the fundamental human rights. ${ }^{11}$

Currently, land and natural resources in Ethiopia are under public ownership. The state and nations, nationalities and peoples are collective owners of land and natural resources. ${ }^{12}$ Furthermore, land laws both at federal and regional levels recognize three types of land holdings; these are private, communal and state holdings. ${ }^{13}$ However, customary land tenures (communal land) are severely undermined especially in the farming community because the law states that communal land can be subject to distribution as private landholding where the need arises.

Notwithstanding three regime changes (absolute monarchy, the Derg, and the present regime), and in spite of various land-based measures, agricultural productivity has fundamentally remained stagnant. ${ }^{14}$ Moreover, given the current population which is over 100 million, demand for land is too high while land is too scarce and private holdings have become fragmented. The vast majority of rural communities depend on subsistence farming, and tenure security is a precondition for reaping the benefits of land rights. ${ }^{15}$ Key to the effectiveness of subsistence farming is the availability of communal lands which

\footnotetext{
${ }^{8}$ Dessalegn, infra note, 14

${ }^{9}$ Hussein Jemma (2004), 'The Politics of Land Tenure in Ethiopia: Experience from South, Paper Prepared for XI World Congress of Rural Sociology, Norway, July 25-30; Chala Dechasa (2015), 'Environmental Management System: During Imperial, Derg and EPRDF Periods in Ethiopia: Review Paper' Vol.5, No.3 Journal of Environment and Earth Science, pp. 1-10.

${ }^{10}$ Ibid.

11 Amartya Sen (2007), Development as Freedom (Oxford University Press 2001) 1-35; Thomas Pogge, Freedom from Poverty as a Human Right: Who Owes What to the Very Poor? (Oxford University) 1-45.

12 Article 40 (3) of the FDRE Constitution.

${ }^{13}$ Article $2(12,13,14)$ of the Federal Rural Land Administration and Use Proclamation No. $455 / 2005$.

${ }^{14}$ Dessalegn Ramato (1984), Agarian Reform in Ethiopia (Scandinavian Institute of African Studies, Uppsala) 22.

15 De Soto, infra note, 104.
} 
are crucial for livelihood diversification in rural Ethiopia. ${ }^{16}$ Communal land is a complementary or sole means of livelihood for the rural poor via mixed farming/ agriculture, i.e., a mix of crop with livestock farming. ${ }^{17}$ Its advantage is more pronounced for women and the youth who are landless.

The preambles of Ethiopia's rural land laws at federal and regional state levels state the need to realize land tenure security. However, communal lands, pastoral lands and state holdings have not been identified and kept in land registry and records towards ensuring tenure security albeit recent effort towards registering communal land in the lowlands. Only private small scale holdings are registered on a massive scale at first and second registration and certification programs. ${ }^{18}$ This article examines the communal land insecurity and its adverse impact in rural livelihood in Hadiya Zone, SNNPRS, so that it can give insights to the problems in Ethiopia at large.

In practice, communal lands are usually considered as 'res-nullius'; i.e., 'ownerless lands' and this renders them susceptible to different encroachments. As revealed in this study, the act of the government and private illegal intrusions are the two major problems that are adversely affecting communal lands.

This article examines the problems affecting communal lands and it addresses the relevant questions in this regard: (i) What is the role of communal lands in securing livelihoods of the rural poor? (ii) What constitutes communal lands in the study area? (iii) What were and/are the causes of tenure insecurity of community lands? (iii) How do land law regimes treat rural communal lands? (iv) Can the government retake communal lands to the detriment of rural poor and what are the gaps? (v) What are the effects of loss of communal lands, and their interface with poverty and fundamental human rights? Empirical data have been collected from the study area through interviews and Focus Group Discussion. Court cases are also used to examine communal land encroachments.

\section{The Nexus between Land Tenure and Poverty}

Land tenure is the relationship among people, as individuals or groups, with respect to land. ${ }^{19}$ According to Rose M. Musyoka \& Herbert Musoga, 'land tenure refers to the mode by which land is held or owned by an individual,

\footnotetext{
${ }^{16}$ Muradu, infra note 70.

${ }^{17}$ Wily, infra note, 56, 34-45.

${ }^{18}$ Sosina Bezu and Stain Holden, (2014), 'Demand for Second-Stage Land Certification in Ethiopia: Evidence from Household Panel Data', Land Use Policy Vol. 41, 193.

${ }^{19}$ FAO, (2017), Corporate Document Repository, Land Tenure and Rural Development: Available at <http://www.fao.org/docrep/005/y4307e/y4307e05.htm>
} 
group or the state and is governed by the laws, customs and practices governing those rights. 20

In pre-1975 Ethiopia, rist tenure system conferred rights in land based on descent from the founder father of the land; while the gult tenure system applied to lands given by the state (in lieu of salary) for those who rendered military services or any other service to the government. Moreover, land can also be owned by individuals, churches, the state and communities. ${ }^{21}$ Before 1975 , land ownership was mostly in the hands of absentee landlords, and tenants were subject to arbitrary eviction. ${ }^{22}$ As Muradu notes:

The pre-1975 State land tenure systems were characterized by exploitative rural tenancy, tenure insecurity and evictions of peasants and pastoralists as a result of initiation of commercial agriculture by the state and private investors especially in late 1960 s and early $1970 \mathrm{s.}^{23}$

During the 1960's and 1970's, managing rural communal land and natural resources such as forests, wildlife and so on, were not designed with the view to securing the livelihoods of the rural poor ${ }^{24}$ even though hunger, starvation and famine were commonplace especially among the rural poor. ${ }^{25}$

In the next phase of land tenure, after the fall of absolute monarchy in 1974, the Derg government transferred ownership of all rural land to the state and distributed the same on the basis of use rights to cultivators. ${ }^{26}$ Furthermore, transfer of land rights was highly restricted, because transfers through sale, lease, exchange, or mortgage were prohibited and inheritance was severely

${ }^{20}$ Rose Mumbua Musyoka \& Herbert Musoga (2015), 'Typologies of Land Tenure and their Impact on Urban Form in Africa: The Case of Eldoret City in Kenya' (Paper Prepared For Presentation at the World Bank Conference on Land and Poverty, Washington DC, March 23-27, 2015.

${ }^{21}$ Bruce, supra note 1; Arthur Schiller (1969), 'Customary Land Tenure among the Highland Peoples of Northern Ethiopia’: A Bibliographical Essay, African Law Studies (1 June 1969): 2-4.

${ }^{22}$ Donald Crummey (2000), 'Land and Society in Christian Kingdom of Ethiopia, From the Thirteen to the Twelfth Century' (Addis Ababa University Press,); John M. Cohen and Peter H. Koehn (1977), 'Rural Urban Land Reform in Ethiopia' No.14, Land Tenure Center University of Wisconsin-Madison, Reprinted by Permission from African Law Studies.

${ }^{23}$ Muradu, supra note 3.

${ }^{24}$ Challa, supra note 9.

${ }^{25}$ Ibid.

${ }^{26}$ Article (5) of the Rural Land Public Ownership Proclamation No. 31/1975 
restricted. ${ }^{27}$ Tenure security was further weakened and land was subject to recurrent redistribution. ${ }^{28}$

Derg's villagization and collectivization program exacerbated the rural poverty by detaching them from their habitual homesteads and fertile land. ${ }^{29}$ Farmlands were usually far apart from villages and were quite inconvenient to manage. ${ }^{30}$ The regime created acute tenure insecurity for rural farming communities and this had unique features of sustaining rural poverty. ${ }^{31}$ Schemes such as 'food for work' launched at the eve of Derg's downfall with the support of foreign donors and intergovernmental organizations, were not fruitful. ${ }^{32}$ There was frequent redistribution of the private holdings and steady encroachments on communal land.

After EPRDF ${ }^{33}$ came to power in 1991, it has sustained the land policy it inherited from its predecessor. There has only been little substantive change with regard to the land rights of rural smallholder farmers, and it is still inadequate to meet the interest of the rural poor in the alleviation of rural poverty. The Constitution confirms the inalienability of landholdings and collective ownership of land by the people and the state. ${ }^{34}$ Thus, discourse on the need for property rights in land is still underway. There is an argument that the land law regime is motivated by political power consolidation, and it has sustained massive poverty due to tenure insecurity. ${ }^{35}$

From the Derg period onward including the current legal regime, Ethiopia's land laws are built on 'egalitarian principle' and 'equity thesis' at the cost of

\footnotetext{
${ }^{27}$ Mengistu Abebe (2016), 'The March 1975 'Land to the Tiller Proclamation: Dream or Reality'? Vol. 2, 1 American Research Journal of History and Culture (ARJHC).

${ }^{28}$ Paul Brietzke (1976), 'Land Reform in Revolutionary Ethiopia' Journal of Modern African Studies, Vol. 14, No. 4. pp. 637-660.

${ }^{29}$ Dessalegn Rahmato (2009), The Peasant and the State: Studies in Agrarian Change in Ethiopia 1950s'-2000s` (Addis Ababa University Press); Muradu A. Srur (2009), 'Land Law and Policy in Ethiopia since 1991: Continuities and Changes', Ethiopian Business Law Series, Vol. 3 Addis Ababa University

${ }^{30}$ Mengistu, supra note 27.

${ }^{31}$ Dessalegn Rahmato (1993), 'Agrarian Change and Agrarian Crisis: State and Peasantry in Post-Revolution Ethiopia', Journal of the International African Institute, Vol. 63, No. 1, pp. 36-55.

32 James Keeley and Ian Scoones (2000), 'Knowledge, Power and Politics: The Environmental Policy-Making Process in Ethiopia', Journal of Modern African Studies, Vol. 38, No. 1, pp. 9-12.

${ }^{33}$ Ethiopian People's Revolutionary Democratic Front

${ }^{34}$ Article 40 (4) of the FDRE Constitution

${ }^{35}$ Daniel, supra note 5.
} 
efficiency. ${ }^{36}$ Even though tenure security is a precondition for reaping benefits that accrue from communal lands, the problem in this regard has not yet been rectified. ${ }^{37}$ Rural poverty alleviation strategies in Ethiopia lacked active public participation and pursued 'top-down approaches' thereby ending up in exacerbating poverty. ${ }^{38}$ Yet, communal lands including pastoral lands constitute more than $61 \%$ of the total land size of the country. ${ }^{39}$ It is also governed by customary norms of a given local people. ${ }^{40}$ These lands are considered as 'ownerless' by the law (de jure) or are simply subsumed under the generic domain of 'state lands'.

This goes against the responsibility of the government to revisit the legal regime with a view to reforming it, including community empowerment by acknowledging the unique features and benefits of community lands to rural livelihoods. This calls for extensive survey and registration of the size and nature of such lands in view of their positive contribution to rural livelihoods if they are legally recognized and protected.

\subsection{The Rural Poor in Ethiopia and the poverty-line threshold}

More than $75 \%$ of the people in poor countries are rural dwellers. ${ }^{41}$ These people live below [UNO] poverty line. ${ }^{42}$ Sub-Saharan Africa hosts more than half of the world's poor. ${ }^{43}$ World Bank study (2016) shows that the international extreme poverty line standard is the threshold below income-US\$1.90 per a day. ${ }^{44}$ The global poor are predominantly rural young, poorly educated, mostly employed [under-employed] in the agricultural sector, and households with more children. ${ }^{45}$ According to 2017 World Bank estimation, the current

${ }^{36}$ Tesfaye Teklu (2005), 'Land Scarcity, Tenure Change and Public Policy in the African Case of Ethiopia: Evidence on Efficacy and Unmet Demands for Land Rights': Available at $\langle w w w . l e a r i n i n g a c e . c o m, d o c\rangle$ accessed on 3 July 2017.

${ }^{37}$ Ege Svein (2000), 'Peasant Participation in Land Reform: The Amhara Land Redistribution of 1997' (Norwegian University of science and Technology). Available at <http://www.researchgate.net> accessed on August 1, 2017.

${ }^{38}$ James Krueger and Others (2013), 'Environmental Permitting in Ethiopia: No Restraint On 'Unstoppable Growth?', Haramaya Law Review, Vol. 1:1, 73.

${ }^{39}$ Mohammud Abdulhai (2007), 'The Legal Status of the Communal Land Holding System in Ethiopia: The Case of Pastoral Communities', International Journal on Minority and Group Rights, 14, 85-125.

${ }^{40}$ Muradu A. Srur, infra note 70.

${ }^{41}$ The World Bank Group, 'Poverty and Shared Prosperity' (2016), International Bank for Reconstruction and Development, the World Bank Washington, DC, p. 42.

${ }^{42}$ Ibid

${ }^{43}$ Id., at 49.

${ }^{44}$ Id., at 51.

${ }^{45} \mathrm{Id}$., at 52. 
population size of Ethiopia is over 100 million. ${ }^{46}$ More than $83 \%$ of Ethiopia's population are rural dwellers. Over 12 million people persistently or at least periodically cannot secure livelihoods. ${ }^{47}$

Agricultural production is extremely vulnerable due to climate variability such as persistent lack of rainfall. One may also wonder that in the advent of ' $E l$ Nino' and 'La Nina Catastrophes '48 (2015/2016 to mid-2017), the rural poor failed to secure livelihoods. ${ }^{49}$ At the time, official declaration by the government indicated that more than 8 million people were in need of food aid. Thus, the rural poor in Ethiopia are small-scale farmers, poorly educated, and live in larger households with more children, landless youth and persons who are (on average) cultivating less than 0.5 hectares of land. ${ }^{50}$ Acute land fragmentation and shortage of cultivable land are among the major challenges to secure livelihoods. ${ }^{51}$ However, without the political will to change Ethiopia's land policy, poverty eradication strategies and programs are futile.

Land is a sole means of livelihoods for more than $83 \%$ of the rural poor in Ethiopia; however, it is misgoverned. ${ }^{52}$ Land has not been efficiently utilized and it has no market value under Ethiopian law while lease auctions by municipalities prove otherwise. The poor and the poorest of the poor constitute about $37 \%$ percent and they live near or below the poverty line with daily per capita income of approximately less than 40 Ethiopian Birr. ${ }^{53}$ Ethiopia is still a

${ }^{46}$ United Nations Population Forecast, on July5/2017 <http://www.worldometers.info/worldpopulation/ethiopia-population/> accessed on July 7, 2017.

${ }^{47}$ IFAD (International Fund for Agricultural Development), Assessment of Rural Poverty in Ethiopia: Available at:

$<$ http://www.ruralpovertyportal.org/web/guest/country/home/tags/ethiopia > accessed on September 5/2017.

48 'El Nino' Catastrophe is a warming of the Tropical Pacific that may occur roughly every three to seven years and lasts for 12-18 months. The opposite of 'La Nina' accompanied by heavy Rain and Cold Weather.

${ }^{49}$ IFAD, supra note 47

50 Ibid

${ }^{51}$ Jon Anderson LRMT and Others (2006), 'Issues in Poverty Reduction and Natural Resource Management' (USAID Washington, DC) 1-7; Belay Habtemariam (2003), 'Livestock and Livelihood Security in the Harar Highlands of Ethiopia', Implications for Research and Development, Swedish University of Agricultural Sciences (SLU).Uppsala, Sweden.

${ }^{52}$ Daniel, supra note 5.

${ }^{53}$ Oxford Poverty and Human Development Initiatives (2017), 'Ethiopia Country Briefing' Multidimensional Poverty Index Data Bank. OPHI, University of Oxford. Available at <www.ophi.org.uk/multidimentional-poverty-index/mpi-country-briefings/. > accessed on January 25 /2017 ; see also, World Bank, Ethiopia's Country Poverty Profile, Posted on October /2017. 
least developed nation, and the poorest of the poor live in Sub-Saharan Africa. ${ }^{54}$ Ethiopia should thus face these facts head on and revisit its land policy to secure the livelihoods of the rural poor and secure tenure, including communal land tenures.

\subsection{Arguments for and against communal land rights}

The nature of a thing is defined (by the black's law dictionary) as a fundamental quality that distinguishes something from other. It is an essence of something. According to Wily, community lands are all lands that fall under the customary governance of the community whether or not this is recognized in national law. ${ }^{55}$ Rural communal lands are lands which rural communities possess and use collectively in accordance with community-derived norms and are areas maintained as the communal property of all community members. ${ }^{56}$ It is rescommunis. Lands for grazing and wildlife, forests and woodlands, mountaintops, sacred localities, lakes and streams within the community lands are usually retained purposely as collective property in which all members have use rights. ${ }^{57}$ A right to use this commons exists within a community where each member has a right to use the holdings of the community. ${ }^{58} \mathrm{~A}$ member of a community may have rights such as grazing cattle on a communal pasture and fishing activities. 59

Although communal lands are essential to the community as a source of livelihood, there are different views regarding the nature of communal lands. According to Hardin, commons are available for many to use, however, it grants only privileges for the users and imposes neither right nor duty. ${ }^{60}$ Moreover, in light of economic assumption, they have no proprietary rights. ${ }^{61}$ Nevertheless, he does not deny that communal lands (commons) are means of livelihoods. But, he urged for better property rights in land, and he advocated for the abolition of communal land tenures and supported private property because there can be the risk of free riding and overexploitation of such resources as

\footnotetext{
${ }^{54}$ See the United Nations' Human Development Index (UNHDP) 2017 Report.

${ }^{55}$ Liz. A. Wily and others (2016), 'What National Laws say about Indigenous \& Community Land Rights' Methodology document from Land Mark: The Global Platform of Indigenous and Community Lands Available at: www.landmarkmap.org. retrieved on March $16 / 2017$.

${ }^{56}$ Liz Alden Wily (2011), The Tragedy of Public Lands: The Fate of the Commons under Global Commercial Pressure (the International Land Coalition).

${ }^{57}$ Ibid.

${ }^{58}$ IFAD, supra note 47.

${ }^{59}$ Ibid.

${ }^{60}$ Garret Hardin (1968), 'The Tragedy of the Commons', Science: New Series, Vol. 162.

${ }^{61}$ Ibid.
} 
every member strives to maximize his/her own economic benefits from the common resource. This line of argument was further confirmed by De Soto (and evolutionary land rights mainstream economists) who preferred property rights in land rather than upholding communal land tenure.

On the other side, Broomy and Cerina argued that communal land is characterized by lands as intra and trans-generational asset. It was and is managed at different levels of social organization and may be used for hunting, grazing, fishing, transit, recreation and biodiversity conservation and so on. ${ }^{62}$ There are also clear rights and duties in respect of the use of these resources. ${ }^{63}$ Broomy and Cerina noted that communal lands are not open access systems or species of state or socialist property. ${ }^{64}$

According to Salman and Munir, communal lands are source of livelihoods for many poor households. ${ }^{65}$ Oketh Ogendo, has objections, to Hardin's view and criticizes the denial of the proprietary nature of the rights of communities and their members in African commons during the colonial period and he also criticizes the absence of compensation during the expropriation of communal lands. ${ }^{66}$

Ostrom's new common pool resource theory, justifies protecting finite resources (common pool resources) such as, grazing lands, forests and irrigation waters by the concerned local people from ruin or depletion by underlining its significance for their needs and future generations. ${ }^{67}$ According to Ostrom, private property is not the only possible way to promote safe protection of the land and attached resources. ${ }^{68}$ Yet, there are overriding interests or individual interests ${ }^{69}$ on communal lands which may include unwarranted encroachments.

${ }^{62}$ Broomy and Cerina, (1989), 'The Management of Common Property Natural Resources: Some Conceptual and Operational Fallacies', Washington DC: World Bank, Discussion Paper No. 57; C. Niyamu Musembi (2006), 'Breathing Life into Dead Theories about Property Rights: De Soto and Land Relations in Rural Africa', Working Paper (Institute of Development Studies, 1-10.

${ }^{63}$ Broomy, ibid.

${ }^{64}$ Ibid.

${ }^{65}$ Mohd S. Salman and Abdul Munir, infra note 75.

${ }^{66}$ Oketh Ogendo, (2002), 'The Tragic African Commons: A century of Expropriation, Suppression and Subversion' University of the Western Cape, Land Reform and Agrarian Change in South Africa an Occasional Paper Series No 24, pp. 1-17.

${ }^{67}$ Elinor Ostrom (1994), Governing the Commons' The Evolution of Institutions for Collective Action (Cambridge (University Press 1990)1-10; E. Ostrom, R. Gardner, \& John. M. Walker, Rules, Games, and Common-Pool Resources (Ann Arbor, University of Michgan Press) 3-23.

${ }^{68}$ Ibid.

${ }^{69}$ FAO, supra note 48 . 
As Muradu notes, communal lands are complementary or sole means of livelihood for the rural poor:

In some occasions, because of the [small size], the low quality of the private farmholdings and rainfall variability, the benefits which the rural poor obtain from commons might by far exceed those obtained from private land possessions. $^{70}$

Tanzania recognizes up to 61 million hectares of the total land as communal property owned and used by some 10,400 discrete village communities. ${ }^{71}$ Some States like Madagascar, Ethiopia and Nigeria attempt to protect rural commons for the benefit of the community with ineffective system. ${ }^{72}$ In the case of Madagascar, rural commons -especially, forested lands and grasslands- are important for the 10 million cattle herders, and yet have been retained as de facto unused or state property. ${ }^{73}$ In Nigeria and Ethiopia, communal lands are subject to change to private holdings or commercial purposes.

Crop farming is not yet the sole source of the livelihoods. The majority of the rural poor's livelihood depends on herding livestock. ${ }^{74}$ Besides, these lands are sole means of livelihood for the landless rural poor. This is further, confirmed by Wily:

Known higher dependence on commons by families without farmlands of their own or farms which are too small to provide full subsistence, it is predicted that land losses will proportionately affect very poor people the most. $^{75}$

${ }^{70}$ Muradu A. Srur (2013), 'Rural Commons and the Ethiopian State Law', Social Justice \& Global Development, University of Warwick (an Electronic Law Journal); Lasse Krantz, 'Securing Customary Land Rights in Sub-Saharan Africa Learning from New Approaches to Land Tenure Reform'(2015) Working Papers in Human Geography, p. 1.

${ }^{71}$ Wily, supra note 56; JM Lugga Kironde (2009), 'Improving Land Sector Governance in Africa: The Case of Tanzania', Paper Presented to the Workshop on Land Governance in Support of the MDGs, Responding to new challenges (The World Bank, Washington DC) $1-5$.

72 Liz A. Wily and D. Hammond, (2001), 'Land Security and the Poor in Ghana: Is there A Way forward'? (Accra,) DFID.

${ }^{73}$ Ibid.

${ }^{74}$ IFAD, supra note 47.

${ }^{75}$ Wily, Tragedy of Public Lands, supra note 56, pp 4-58; see also, Mohd S. Salman and Abdul Munir (2016), 'Common Land Resources, Livelihood And Sustaining The Rural Poor in India: A Geographical Analysis, European Journal of Geography, Vol.7, No. 4:6 -18 . 
Thus, secure communal land tenure or access to land is vital to address rural poverty. ${ }^{76}$ It also serves as social guarantee or insurance to secure livelihoods of the rural poor. ${ }^{77}$

\section{The Role of Access to Land in Livelihood and Human Rights}

Livelihood refers to the means of securing the necessities of life such as food, water, shelter and clothing. ${ }^{78}$ These basic necessities such as food, potable water, health facilities, educational opportunities, housing, etc., are the main facets to assure adequate living standards. ${ }^{79}$ According to FAO, the household's livelihood security is strongly related to living with dignity. ${ }^{80}$ Furthermore, the issue relates to sustainable livelihood opportunities for the next generation. ${ }^{81}$

Land provides nearly all the food used in the world and will continue feeding life on earth. ${ }^{82}$ Access to land is effective in helping rural households to generate higher income and feed their family ${ }^{83}$ and it is important for socio-economic development and poverty reduction. It also serves as a gateway for many civil and political rights. ${ }^{84}$

Poverty negatively impacts more on vulnerable people within a community. ${ }^{85}$ The continuation of extreme poverty in developing countries amounts to

${ }^{76}$ Akand M.F Uddin and Jabin T. Haque, 'Agrarian Transition and Livelihoods of the Rural Poor: Agricultural Land Market' (Bangledish, UnnayanOnneshan,-the Innovators) 4-5.

${ }^{77}$ Wily, supra note 56.

${ }^{78}$ Livelihoods defined as by Oxford dictionary: Available at <https://en.oxforddictionaries.com/definition/livelihood> accessed on March 27/2017

${ }^{79}$ R. Chambers \& GR Conway (1992), 'Sustainable Rural Livelihoods: Practical Concepts for the 21 st Century' IDS Discussion Paper No. 296, Brighton, UK, Institute of Development Studies.

${ }^{80}$ Scoones Ians, Sustainable Rural Livelihoods Framework Analysis. Available at:<https://www.staff.ncl.ac.uk/david.harvey/AEF806/Sconnes1998.pdf>accessed on June 25/2017

${ }^{81}$ T.R. Frankenberger and M.K. McCaston, FAO, The Household Livelihood Security Concept (citing Chambers \& Conway, supra note 79). Available at <www.fao.org/docrep/X0051T/X0051t05.htm> accessed on July 23/2017

${ }^{82}$ Lindsay, infra note, 114.

${ }^{83}$ Elisabeth Wickeri and Anil Kalhan, infra note, 109.

${ }^{84}$ Thomas Pogge, World Poverty And Human Rights (London Polity Press 2002) 115<http://www2.ohchr.org/english/issues/poverty/expert/docs/Thomas_Pogge_Summary. pdf, > accessed on May 52017.

85 Denis G. Arnold (2010), 'Transnational Corporations and the Duty to Respect Basic Human Rights' Business Ethics Quarterly 372-398: see also, Arnold, D.G. \& Williams, L.H.D, (2012), 'The Paradox at the Base of the Pyramid: 'Environmental Sustainability and Market-based Poverty Alleviation', International Journal of Technology Management, $60(1 / 2)$ pp. 44-59. 
violation of human rights. ${ }^{86}$ Furthermore, its severe forms amount to a violation almost all socio-economic rights, and negatively affect civil and political rights through marginalization and discrimination. ${ }^{87}$

Accordingly, the right to livelihoods is backed by both national and international human rights declarations, Conventions and Instruments. The Universal Declaration of the Human Rights (UDHR) stipulates that 'everyone has the right to adequate living standards', and that means, both social and economic means shall be facilitated without discrimination. ${ }^{88}$ Similar legal provisions are embodied in the International Convention on Economic, Social and Cultural Rights (ICESCR) which protects the right to adequate standard of living. Those numerous economic, social and cultural rights enshrined in the UDHR and ICESCR are intimately connected to access to land, including the rights to housing, food, health and work. ${ }^{89}$

In Ethiopia both UDHR and ICESCR and other human rights instruments are adopted and ratified and are thus considered as an integral part of Ethiopia's law in accordance with articles 13(1) and 9(4) of the FDRE Constitution. Ethiopia is thus duty bound to ensure adequate living standards to its citizens. It is to be noted that Article 43(1) of the Constitution expressly states the right to improved living standards and to sustainable development. To this end, Article 89(1) obliges the government to formulate policies to ensure that all Ethiopians benefit from the country's resources. The realization of these rights, inter alia, envisages protection against eviction ${ }^{90}$ including non-eviction from community lands. The state may not be justified not to fulfill this objective and rather it obliges the government to work hard to address the problems that relate to livelihoods in light of the nature of human rights which are interrelated, interdependent and indivisible.

\footnotetext{
${ }^{86}$ Ibid.

${ }^{87}$ R. Haug \& E. Ruan (2002), Integrating Poverty Reduction and the Right to Food in Africa: Available At: http://www.Nlh.No/Noragric/Publications/Reports/Noragricrep2b.Pdf, accessed at 3 April, 2017.

${ }^{88}$ UDHR, Article 25.

${ }^{89}$ Elisabeth Wickeri and Anil Kalhan, infra note, 109.

90 Article 41 (4) of the FDRE Constitution.
} 


\section{The Legal Regime on Communal Land Rights in Ethiopia}

\subsection{The FDRE Constitution}

Land laws and policies of various countries address land tenure issues including the protection of communal land rights of the local people. For instance, Ghana, Tanzania and Botswana, South Sudan, etc., formally recognize community land in spite of differences in the degree of effectiveness. ${ }^{91}$ Ghana's constitution has recognized $80 \%$ of the communal land tenure system. ${ }^{92}$

Article 40(3) of the FDRE Constitution provides that land is the common property of Nations, Nationalities and Peoples of Ethiopia'. Under Article 51(5) of the FDRE Constitution, the federal government is entitled to enact laws on the utilization and conservation of land and natural resources. On the other hand, the power to administer land and natural resources is the responsibility of the regional states as per article 52(2)(d) of the same Constitution. However, the issue of communal land is not well articulated, even though it is mentioned in various provisions in a manner that does not coherently articulate communal rights and their implementation.

\subsection{Federal rural land law on res communis}

Communal lands under FDRE rural land legislation refers as rural land, which is allocated by government to local residents for common grazing, forestry and other social services. ${ }^{93}$ Thus, customary rights are undermined and the state has an overarching role. Communal lands are subject to change to private holdings or be allocated for other commercial or non-commercial purposes as found appropriate. ${ }^{94}$ Thus, the status of communal land is insecure even compared to private holding which is largely registered and certified. In practice, there are no communal landholdings identified and registered in the land registry. The state does not give due attention to communal land and it often considers it as res nullius, thereby rendering it susceptible to distribution as private landholding at the discretion of the government.

There is a new move to reform the land law in Ethiopia. The 2007 revised draft federal rural land legislation, under Article 2(4) while defining the state holdings, confirmed that communal lands could exist irrespective of government allocation. Furthermore, under Article 2(11) of the draft proclamation, recognition is to be accorded to communal land rights as it exists

\footnotetext{
${ }^{91}$ Wily, supra note 56.

${ }^{92}$ Ibid.

${ }^{93}$ Article 2(13) of the Federal Rural Land Administration and Use Proclamation, No. $456 / 2005$.

${ }^{94}$ Id., Article 5(3).
} 
in different forms. Upon approval, the draft legislation needs detailed subsidiary laws that recognize and protect communal lands.

\subsection{Regional Rural Land Laws on Res Communis}

There are two distinct features of communal lands according to Ethiopian land laws. It is a state grant as per the federal rural land law but community ownership is recognized ipso facto according to some laws of regional states. According to rural land laws of Oromia, SNNPRS, Ethiopian Somali, and Afar regional states, communal lands are recognized and homage is paid to the community norms. In these regional states, communal holdings constitute a land which is outside both state holdings and private holdings. ${ }^{95}$ Hence, lands which are not designated under private or state holdings are communal holdings. Yet again, these lands are subject to distribution to land users and could easily be given to investors.

The rural land laws of the regional states duly recognize the use rights of communal lands. However, the practical problems relate to considering the government as owner of the communal lands, and the act of assigning communal land for any other purpose including their conversion to private holdings. This renders communal land insecure and undermines its socioeconomic contribution to the rural community. As highlighted above, communal lands indeed positively contribute towards enabling mixed farming and the retention of cultural heritages of different communities. ${ }^{96}$

Owing to the steadily increasing population pressure that is exacerbating land fragmentation and decline in productivity, many households have failed to secure their livelihood. It is thus essential for Ethiopia to ensure communal lands rights in both agricultural and pastoral communities (for the benefit of the rural poor) towards securing livelihood and diversification of economic activities. It is to be noted that communal lands are essential, especially for the landless who engages in modest scales of cattle rearing, with due caveats against encroachments by its individual members to use communal land for private cultivation.

95 Article 2 (3) of the Oromia National Regional State Rural Land Administration and Use Proc.No.130 /2007; Article 2(14) of the SNNPRS, Rural Land Administration and Use Proc. No.110/2007; Article 2 (17) of the Afar Regional State National Regional State Rural Land Administration and Use Proc. No 49/2009: see also, The Ethiopian Somali National Regional State Rural Land Administration And Use Proc. No. 128/2013.

96 Diversified Farming, 'Define Diversified Farming at Dictionary.com': Available at: $<w w w$.dictionary.com/browse/diversified-farming > accessed 25 June 2017: see also, Liz A. Wily (2012), 'Customary Land Tenure in the Modern World Rights to Resources in Crisis: Reviewing the Fate of Customary Tenure in Africa' Brief. No, 1, 3 


\section{Challenges of Communal Land Registration and Certification}

Land registration means 'the process whereby information on the expression of rural land use rights and holding is gathered and analyzed' ${ }^{97}$ To realize these tasks, various countries have land policies and laws. ${ }^{98}$ In the 1950's and 1960's, land registration programs in Africa were designed to administer and recognize land rights and replace customary land rights by formal (state) laws. ${ }^{99}$ At present, there are states that predominantly use laws in dealing with communal lands, while others have recognized community lands that are held under customary rules. ${ }^{100}$ Irrespective of the routes chosen, many countries have secured communal land tenure in various forms.

Tenure security in communal land protects communities from arbitrary eviction, and it secures their use rights over communal lands. As Solomon states, tenure security "defined broadly, pertains to the assurance, confidence, or expectations" that landholders are ensured "to remain in physical possession of, and the rights to, and the fruits of their land holdings and investments by their labor excluding the state, private individuals and other entities, either in the course of use or transfer". ${ }^{101}$

Under insecure tenure, on the other hand, rights to land are threatened by competing claims, and can even be lost as a result of eviction. ${ }^{102}$ Without security of tenure, households or families are considerably impaired in their ability to secure sufficient food and to enjoy sustainable livelihoods. ${ }^{103}$ The introduction of titling (via certification for land rights) positively contributes toward tenure security if it goes beyond mere records of landholdings and parcel locations.

Formalization theorists contend that titling via certification could bring tenure security which is advocated by De Soto, Klausand others. ${ }^{104}$ They argue

\footnotetext{
${ }^{97}$ Article 2(15) of the Federal Rural Land Law, supra note 95; Article 2 (17) of the SNNP Regional Rural Land Law, supra note 95.

${ }^{98}$ Liz A. Wily, supra note 72.

${ }^{99}$ Ibid

${ }^{100}$ Knight, supra note 3

${ }^{101}$ Solomon Fikre (2015), the Challenges of Land Law Reform, Smallholder Agricultural Productivity and Poverty in Ethiopia (PhD Thesis, Warwick University, School of Law) 53.

${ }^{102}$ FAO, supra note 81 .

${ }^{103}$ Ibid.

${ }^{104}$ De Soto Hernando (2000), The Mystery of Capital: Why Capitalism Triumphs in the West and Fails Everywhere Else (New York: Basic Books) 166-217; Jean-Philippe Plateau (1996), 'The Evolutionary Theory of Land Rights as Applied to Sub-Saharan Africa: A Critical Assessment' Vol. 27 pp 29-86 Blackwell Publishers; Yigremew Adal (2002), 'Review of Landholding Systems and Policies in Ethiopia under the Different Regimes', EEA/Economic Policy Research Institute, Working paper No. 5.
} 
that clearly defined property rights to land and the ability to draw on the state's enforcement capacity will, inter alia, reduce the risk of eviction, increase incentives for land-related investment (development). ${ }^{105}$ Formal property rights are also the key to poverty reduction by unlocking the capital potential of assets held customarily by the poor people. ${ }^{106}$ Yet, especially for the poor and persons in special need, formality increases the need for land owners to expend resources to stake out or defend their claims. ${ }^{107}$

Meanwhile, however, the role of customary rules over communal land ownership must not be undermined. Perz et al argue that even if formalization proceeds via titling, the task of titling by itself may not be sufficient to ensure tenure security. ${ }^{108}$ According to Elisabeth Wickeri and Anil Kalhan ' $[t]$ enure security in land or secure usage rights in land, in the form of formal legal, customary or religious rights, can provide more predictability and secure access to fundamental rights, including to food, housing, water, and health'. ${ }^{109}$

Thus, the issue as to how and in whose name communal lands could be registered needs to be addressed. Ghana's experience shows that, traditional authorities are eligible for the title. Furthermore, China's current statutes enable rural agricultural lands to be collectively owned. A positive development in this regard is that various regional rural land laws in Ethiopia stipulate that landholding certificate for communal land shall be prepared in the name of the beneficiary community and be kept at Kebele administration office. ${ }^{110}$ However, these laws are not effectively implemented.

\section{Compensability of Res Communis}

An owner of private property has the right to use, transfer, reap benefits and claim compensation in the event of legitimate expropriation. ${ }^{111}$ According to Article 40(8) of the FDRE Constitution, private property is subject to

\footnotetext{
${ }^{105}$ De Soto, Ibid.

106 Ibid.

${ }^{107}$ Klaus, supra note 5.

108 Perz and Others (2014), 'Private and Communal Lands? The Ramifications of Ambiguous Resource Tenure and Regional Integration in Northern Bolivia', International Journal of the Commons.

${ }^{109}$ Wickeri Elisabeth and Kalhan Anil (2010), 'Land Rights Issues in International Human Rights Law,' Malaysian Journal on Human Rights, Vol. 4, No. 10: Drexel University Earle Mack School of Law Research Paper : Fordham Law Legal Studies Research Paper No. 1921447.

${ }^{110}$ See Article 5 (12) of the SNNP Rural Land Law; Article 15 (16) of the Oromia Rural Land Law.

${ }^{111}$ FDRE Constitution Article 40 sub articles (1), (7) and (8).
} 
expropriation for public purpose. This is also embodied in other legislation. ${ }^{112}$ Yet, what constitutes public purpose lacks clarity and again the situation is further complicated when the taking involves communal land.

The public interest test can, for example, be contested before the courts in countries like USA, UK and many other African countries. The underlying advantage of restricting wider construction of public purpose in Ethiopia is that it will ensure tenure security for individual holdings or communal holdings. Such restriction against wider construction enhances better development and discourages unwarranted intrusions by the government. It could also address the gaps that enhance conflicts in this regard.

Compensation in Ethiopia upon expropriation is nominal. Compensable rights in land only relate to improvements made on the land or buildings on the land. An evicted person can only contest the amount of compensation before the court; and cannot contest whether there is public interest. Land use rights (or land) per se are not considered as property in Ethiopia for the law confirms that it belongs to the state and the people. Tenure insecurity is graver in communal lands because such lands have no formally defined owner. This gap is mainly attributable to the legal regime (at federal and regional state levels) that are vague and confusing with regard to legal titling thereby confirming lack of defined/identified owner for the purpose of compensable interest.

As the experience of various countries such as Ghana, Tanzania and Botswana indicates, communal holdings are compensable. In Tanzania, even bare (undeveloped lands) are compensable. In Ghana, traditional authorities are entitled to exercise full ownership on the land on behalf of their communities; and hence compensation is due to the community in the event of expropriation. ${ }^{113}$ At present, communal lands are statutorily held by groups. ${ }^{114}$ China recognizes the rights of a collective entity ${ }^{115}$ with regard to rural agricultural land. The law treats the collective entity as the holder of the compensable interest in land.

Recent good practices in Ethiopia involve pastoral lands, and this can be scaled up to communal lands used by non-pastoral communities. Borena communal land (pastoral land) has been registered and certified in the name of

112 Article 2(5) of the Expropriation of Land holdings for Public Purposes and Payment of Compensation Proc. No. 455/2005.

113 John Tiah Bugri (2013), 'Issues and Options for Improved Land Sector Governance in Ghana': Application of the Land Governance Assessment Framework', World Bank, Synthesis Report, pp. 11-23.

114 Jonathan Mills Lindsay (2012), 'Compulsory Acquisition of Land and Compensation in Infrastructure Projects' Vol. 1, Issue 3 p.2; PPP in Infrastructure Resource Center for Contracts, Laws, and Regulation (PPPIRC).

${ }^{115}$ Ibid. 
Abaa Dheeda, and its effect and modalities of exercising this right remains to be seen. The same effort is underway in Afar region. The certification process in Borena was preceded by intensive discussion among communities and government authorities.

The experience of countries such as Tanzania, Botswana and Ghana confirm that local communities can be consulted and informed when communal lands are expropriated for public purpose. On the contrary, such public participation is either nominal or unavailable in Ethiopia. Thus, the amount of compensation is not commensurate with the cost of alterative livelihood because it is only the private property on the land (without including the value of land) that is considered in the valuation of compensable property. And, in the case communal land, even such nominal compensation is not available owing to lack of individual title.

\section{Communal Lands and the Concerns of the Rural Poor: Experience from Hadiya Zone, SNNPRS, Ethiopia}

Southern Nations, Nationalities and Peoples Regional State (SNNPRS) is structured into 14 zones and four special Woredas. The region's economy is based on subsistence farming and mixed agriculture. In some parts of the region (e.g. pastoral communities), people's livelihoods are based on livestock herding. ${ }^{116}$ The region is one of the most densely populated rural areas in Ethiopia and it is in the midst of ecological crisis. Farmland is too scarce and heavily overutilized. The Rainfed agriculture is vulnerable due to climate changes and degraded resources. Even when farming seasons are good, more than half of the youth in the region are either unemployed or underemployed, owing to the lack of farmland. ${ }^{117}$ Most families in the region live on less than 0.50 US dollars per day. ${ }^{118}$

116 Roots Ethiopia is a 501(c) 3 Non-Profit organization that works in Southern Ethiopia and supports locally managed projects to help the most vulnerable families and children in this Region of East Africa; available at <http://www.rootsethiopia.org/about-the-region/> accessed on July 15, 2017; see also , RIPPLE was a five-year research programme consortium funded by the UK's Department for International Development (DFID) between 2006 and 2011, 20 Feb 2013 <http://www.rippleethiopia.org/page/snnpr> accessed on 16 August 2017

${ }^{117}$ Ibid.

118 USAID, 'Livelihoods Ethiopia Southern Nations, Nationalities and Peoples Region (SNNPR) Livelihood Zone Reports SNNPR Follow-On to Regional Livelihoods Baseline Study', Available at $<$ http://pdf.usaid.gov/pdf_docs/Pnadj866.pdf $>$ accessed on 25/2018. 
Hadiya is one of the zonal administrations in the region. It shares boarders in the North with Silti and Gurage, in the south with Wolayitta, in the south east with Kambata and Tambaro, in the West with Omo River which separates it from Oromia region and the Yem Special Woreda. It is structured into 10 Woredas and two City administrations. The current population of the zone is estimated to be over 1.6 Million. ${ }^{119}$ The population density per square kilometer is more than $342.64 .^{120}$ The average rural household has less than 0.6 hectare of land compared to the national average of one hectare of land and an average of 0.89 for the region. ${ }^{121}$ More specifically, the study areas focused at Duna Woreda (Haa, Lee and Semen Wagabeta Kebeles) and at Gibe Woreda (Gemojja, Ollawa and Halilicho Kebeles). The rural poor are leading their livelihoods by subsistence agriculture, especially mixed farming.

With respect to land tenure, tenancy had a long history, in Hadiya. ${ }^{122}$ The feudal system introduced the gebar system with its entrenched exploitative landlord-tenant relationship in the zone. ${ }^{123}$ The farmers were harshly exploited by Melkegna's (landlords) in collaboration with local land lords. ${ }^{124}$ During this period, there was no tenure security in land rights whether it was communal or private holding. The livelihood of the inhabitants was overwhelmingly affected.

During the Derg regime tenure insecurity due to land redistribution continued in spite of the land reform. However, 'Land to the tiller' gave temporary relief to the society. It was initially welcomed by the inhabitants of Hadiya. Nevertheless, the recurrent redistribution policy and forced resettlement programs had led to tenure insecurity. Thus abject poverty of the rural poor continued. The current EPRDF led government has opted to pursue the public ownership of land regime. There are no effective transformative rural strategies and land law reforms. In effect, the rural poor in Hadiya zone still lives under poverty. The land regime of all the three governments, therefore, worked for the ruling groups and the political elites as an instrument of political control or as a scheme of exploitation.

Land tenure has been and is still a contentious public policy issue in Ethiopia. ${ }^{125}$ The politics behind land issue has the underlying assumption that

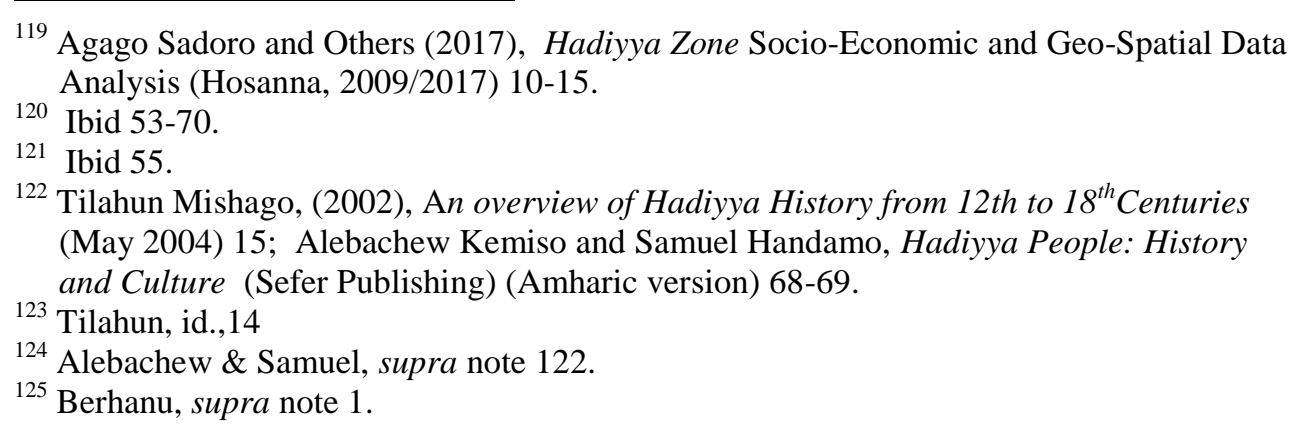


'who controls land controls power', 126 in addition to which it is the main source of all economic pursuits and source of livelihoods. Land is flesh and blood for Hadiya people. ${ }^{127}$ Communal lands, in particular, are of substantial use for more than $75 \%$ of the rural poor and the landless. The youth and families with many children are overwhelmingly dependent on communal land. It complements crop farms or can be sole means of livelihood for the landless. ${ }^{128}$

According to respondents in this study, incursion on community lands entails loss of livelihoods. The long-standing practice among Hadiya population is that community lands serve as 'alternative' medium to secure livelihoods. Smallholder farmers in Hadiya Zone are still engaged in livestock farming and, they reserve plots from small scale farmlands, often uncultivated (baadulliuulla) to fodder (for their cattle). The fodder from community land is thus indispensable owing to the land shortage.

According to some respondents, Hadiya population has special attachment to their cattle. It is traditionally believed that the spirit of traditional gods (waa'a) dwells in the cattle. Besides, it is source of wealth and social status. The tradition is still practised and is known as garad or abgaz, or woganaa in local parlance. This, traditional belief is expressed by tibimma practice, i.e., counting 100 (hundred cattle) and kummimma practice which means counting more than 1000 (thousand cattle). ${ }^{129}$ These titles enable title holders to serve in gas seera, i.e., a traditional administrative power in customary institutions of the people. ${ }^{130}$ Even though enhanced numbers of cattle for the purpose of social status is impractical under the current realities, these institutions have positive functions in resolving conflicts and in dealing with offences ranging from petty to grave criminal cases (such as homicide) by using customary ritual and compensation known as xiigguula. This institution also resolves land disputes such as trespass, boundary issues or other claims in land rights. ${ }^{131}$ Hence, communal land is a key to livestock rearing and subsistence farming to secure and enhance livelihoods and societal cohesion. ${ }^{132}$

\footnotetext{
${ }^{126}$ Hussein, supra note 9.

${ }^{127}$ Interview with persons who have the traditional count of more than 100 Cattles on April 21/2017 at Lee Wagabeta Kebele.

${ }^{128}$ Ibid.

${ }^{129}$ Ibid.

${ }^{130}$ ErgogeTesfaye (2016), 'The Ancestral History and Traditional Administrative Structure of Hadiyya Society: an Ethnic Group in Ethiopia' Historical Research Letter, ISSN 2224-3178 (Paper) Vol. 32, p.1.

${ }^{131}$ Alebachew supra note 122.

${ }^{132}$ IFAD supra note 53.
} 


\section{Res Communis: Hanging in the Balance}

Communal lands in Hadiya are governed by community norms. No state law has come up with creating new and robust rights over communal lands. The available commons are only for common use unlike Wily's definition of community land which includes individual farm lands. Hadiya people consider it as inherited from their forefathers. And, they believe that those communal lands are source of all livelihoods, especially for the rural poor. ${ }^{133}$ Empirical evidence shows that perceived tenure security problems in Ethiopia relate to fear of land redistribution and expropriation. ${ }^{134}$ In the context of communal lands, government encroachment (highlighted below in Sections 7.1 to 7.4) and private intrusions (Sections 7.5) constitute major challenges.

\subsection{Res communis allocated for 'investment'}

In Ethiopia, allocation of agricultural land to foreign or domestic investors is an agenda in development plans. ${ }^{135}$ The promised benefits of investment promotion are, inter alia: economic development, technology transfer, job creation to locals thereby reducing joblessness, enhanced food security and export earnings. ${ }^{136}$ Based on these promises of benefits, allocation of land for investment is a common practice in both urban and rural areas. The investment sectors in rural areas have mostly failed to meet their promises, and are on the contrary endangering small scale farming, mixed agriculture, forestry and livestock farming.

The land selection criterion for investment is usually arbitrary because the most favorite criterion is 'ownerless land', which in Ethiopia is unduly equated with land with no defined claimant. ${ }^{137}$ Communal land is by default eligible to be allocated for investment. This parameter is problematic because it easily subjects communal lands to investment without the need to consider issues of compensation. Communal lands located particularity at Halillicho, Gamojja, Ollawwa and Lee and Semen Wagabeta Kebeles were subject to such hostile takeover. Although, the measure amounted to eviction, no compensation issues were entertained owing to the absence of community landholding title and the subsequent difficulty to prove compensable interest.

\footnotetext{
${ }^{133}$ Focus Group Discussion, held at Lee-Wagabeta Kebele in the presence of 11 Persons on 20 April 2017

${ }^{134}$ Daniel, infra note 153

${ }^{135}$ Dessalegn Rahmato (2011), 'Land To Investors: Large-Scale Land Transfers In Ethiopia', Forum For Social Studies, Addis Ababa, Ethiopia; Daniel Behailu (2015) 'Large-Scale Land Acquisitions in Ethiopia- Towards Attracting Foreign Direct Investment', JLAEA, Vol. 3 Issue 1.

${ }^{136}$ Dessalegn, Ibid.

${ }^{137}$ Ibid.
} 
According to the Focus Group Discussion ${ }^{138}$, communal lands are 'common heritage' and are used by the community in common and jointly. As a result, everyone has the right to enjoy benefits from communal lands albeit lack of recognition from the state law. The local authorities have taken a position that undermines rights over communal lands and they consider traditional cattle rearing as imprudently huge and unproductive. They consider the legacy as obsolete, and they believe that it should be replaced by modern cattle rearing system. ${ }^{139}$ It is, however, to be noted that, such projects should be inclusive which can be conducted without evicting members of the local communities.

There are no other alternatives that are availed to communities as communal lands are taken. A greater part of the lands allocated to investors remains undeveloped. For example, more than ten investment projects were cancelled due to failure to develop the land as per the investment agreement. ${ }^{140}$ Thus, the hostile takeover does not facilitate Ethiopia's rural poverty alleviation strategies and improve livelihoods of the rural poor.

A case that involves foreign direct investment (FDI) illustrates hostile takeovers of communal lands. In Giba Green Helmute Fruits and Vegetables Farming vs some members of Ollawa Kebele Community, (Gibe Woreda First Instance, Court File No. 03029/2005), communal lands were given for investment to produce fruits and vegetables. The local community protested against the investment project, and it was eventually violent. This has opened a Pandora box which can entail social crisis. The investment was destroyed by the community. Other similar incidents are quite common in SNNPRS as it is true in other parts of Ethiopia. The issue of tenure security including the recognition and protection of communal lands thus deserves due attention.

In terms of benefits that accrue from investments, there should have been agricultural technology transfer, job creation and positive contribution in the livelihood of the rural poor. On the contrary, what usually transpires is loss of communal and privately-held land and the eviction of smallholder farmers thereby worsening the livelihood of the rural poor. During interview with key informants, it was confirmed that an individual can annually earn an average of ETB 7,000 to 30,000 from the sale of cattle and dairy products by merely breeding cattle on communal lands. They confirmed that the income enhances rural livelihood.

\footnotetext{
${ }^{138}$ FGD, supra note 133.

${ }^{139}$ Interview with an Expert at Hadiyya Zone of the office of Investment.

${ }^{140}$ Ibid.
} 
According to Dessalegn Rahmato, it is easy for the government to allocate community lands for investment by using austere clause like ownerless test. ${ }^{141}$ Unless due care is taken against taking the lands of the rural poor, it may end up in sustaining poverty. ${ }^{142}$ Karol Boudreaux observes:

When land tenure is secure, land can be a cornerstone for economic growth and an incentive for investment, but when land rights are insecure, this can lead to conflicts, instability and the exclusion of vulnerable groups, such as women, indigenous people and the poor. ${ }^{143}$

The facts gathered from vulnerable groups via interview and which is confirmed during Focus Group Discussion reveals that the rural poor, especially women, the elderly and the disabled were the most disadvantaged. They claimed that they are robbed of their communal grazing lands.

In another case, at Semen Wagebetta Kebele, located at Duna Woreda, a local investor appropriated 68 hectares of communal land for agricultural farming. However, more than 16,000 households were using this land for livestock grazing and mixed farming. The public resented and protested against such measure. Even if there was public consultation to persuade the community, the investment could not be operational. ${ }^{144}$

\subsection{Encroachment on res communis and sale}

The Haa-wagebetta and Lee-Waggebetta Kebeles are two of the 30 rural grassroot level administration units in Duna Woreda, which are endowed with rich community lands. It was claimed that communal lands in these neighbouring Kebeles constituted more than 4,700 hectares before three decades. The local people use these lands for the purpose of agricultural diversification. Nowadays, it has been continuously shrinking. However, over 2,600 households live in the locality and above 16,000 individuals depend on subsistence farming through mixed agriculture. ${ }^{145}$ Owing to rapid population growth and the unavailability of land to the rural youth and the landless, communal land is very crucial. ${ }^{146}$

However, more than 45 hectares of the communal lands were given as a Kebele's contribution for the 'Grand Ethiopian Renaissance Dam' construction since 2017. The land was sold via informal land deals by officials to raise fund for developmental projects including the GERD. The de facto informal land transactions and the sale of community lands are rampant and such transactions

\footnotetext{
${ }^{141}$ Dessalegn, supra note 135.

${ }^{142}$ Daniel, supra note 135.

${ }^{143}$ Karol Boudreaux, USAID, 'What is Land Tenure?' available September, 182017 <https://www.land-links.org/what-is-land-tenure/> accessed on 6 July 2017.

${ }^{144}$ Hadiyya Zone Investment Unit is re-structured into Hadiyya Zone Office of Investment.

${ }^{145}$ Interview held with Kebele Administrators at Lewgabeta and Haa Wagebeta Kebeles.

${ }^{146}$ Ibid.
} 
at times involve corrupt practices. ${ }^{147}$ This act also contravenes Article 40(3) of the FDRE Constitution which forbids the sale of land or other means of exchange. Based on the reading of this provision in conjunction with Article 1678(b) of the Civil Code, contract of sale with unlawful object is of no effect. The transaction is thus void from its very outset, and the land can be taken back.

\subsection{The impact of urbanization and rural small-scale enterprises on communal lands}

At different times, over 52 hectares of land have been allocated to farmers evicted from peri-urban areas due to urban expansion. Moreover, at Semen Wagebetta Kebele, over 70 hectares of the communal lands were taken to establish a new urban center. Both local residents and others had access to land in the new urban center. However, persons with disabilities, the youth and the rural poor were unable to pay lease price. Moreover, the new urban center does not fulfill the minimum threshold of urban structure, and no compensation was paid to the community whose land was taken.

One of the development and poverty alleviation strategies in rural Ethiopia (including SNNPRS) encourages the formation of rural small-scale enterprises or cooperatives that can be engaged in activities such as mixed agriculture, environmental rehabilitation and livestock farming. ${ }^{148}$ The eligible persons to access and use the enterprises are the landless youth (aged 15-34), farmers who possesses less than 0.25 hectares of cultivable land and unemployed persons. ${ }^{149}$ These small enterprises or associations are given communal lands. Such allocation of land has continued even though the objectives of these enterprises are hampered by different factors such as lack of adequate credit, facilities, knowledge and skills. ${ }^{150}$

More than 75 hectares of community lands in Hadiya Zone are occupied by small-scale enterprises. The enclosed land for the enterprises are not efficiently developed, and members of the enterprises merely cut down and sell grass from the lands, contrary to the rationale stated to justify the takeover of community lands. There are also instances that involve renting out these lands, and even worse, there are plots that are sold to individuals through informal deals in collaboration with Kebele officials. According to respondents, the youth and

\footnotetext{
${ }^{147}$ FGD, supra note 133.

${ }^{148}$ SNNPRS, Rural Youth Job Opportunity and Development Package Manual (in Amharic 2009); SNNPRS, Rural Job Opportunity and Development Agency Establishment Regulation No. 105/2013; see also, SNNPRS Revised Executives Organs Reestablishment Proclamation No.131/2015.

${ }^{149}$ Ibid.

${ }^{150}$ Interview held with Small Scale Enterprises and Cooperatives.
} 
local poor are protesting against new allocations because of the former allocated lands have not been utilized based on the objectives they were meant to serve. The program that merely targets at haphazardly taking communal lands in the guise of small-scale enterprises should thus be revisited because genuine and value adding economic pursuits need shades with modest size and not community lands.

\subsection{Public institutions and community land}

The majority of public institutions are established on community lands. More often, evicted smallholder farmers (due to expropriation) are relocated to community lands. Such encroachments by public institutions are indeed widespread. In an interview held with a public official in charge of land administration and use core business process, the response was as follows:

Communal lands are under public domain or state ownership. The local government has no financial capacity to compensate in case private holdings are expropriated. Hence, communal lands under the Woreda's jurisdiction are subject to allocation for any development project and as replacement of expropriated private holdings. ${ }^{151}$

After such intrusions, the size of new holdings usually increases continuously if it is adjacent to community land that has no defined owner. Often than not, the encroachment is done with the collaboration of corrupt local officials.

\subsection{Private Intrusions on communal lands}

Both federal and regional rural land laws in Ethiopia recognize private, state and communal rural holdings. ${ }^{152}$ Smallholder farmers have the right to use land in their possession, and illegal appropriation for personal use or trespass to lands under state or community holdings is prohibited. However, private appropriation or illegal intrusion on communal lands for personal benefit is rampant. According to the respondents in this study, more than 85 hectares of community lands are appropriated by private intruders, within this past two decades. The respondents revealed that Kebele officials facilitate such intrusion (often for money) and legalize (formalize) the occupation later on. ${ }^{153}$ Hence, private intruders, public officials and persons who conspire with them should have been rendered liable under criminal law. However, law enforcement is weak in the Hadiya Zone (as in the nation at large) thereby encouraging encroachment throughout Ethiopia.

\footnotetext{
${ }^{151}$ Interview with expert from Rural Land Administration and Use Core Business Process, 23 April 2017.

152 The Federal Rural Land Law, Article 2, Sub-articles (13, 14 and 15): see also SNNPRS rural land law, Article 2 sub articles (13,14 and 15).

${ }^{153}$ FGD, supra note 133.
} 


\section{Conclusions}

The conception of communal land varies under the federal and regional laws. Communal holdings are lands which are neither state nor private holding. These lands may be government creation/entitlements based on the federal rural land law, regional laws, or they may be considered as communal lands by the custom of a given community. In Ethiopia, the land regime has been exploitative during the periods of absolute monarchy, and it has been often used as instrument of control since 1975. Both federal and regional rural land laws uphold government ownership of land, and communal land is subject to different sorts of encroachments. Therefore, Ethiopian rural land laws do not sufficiently recognize communal holdings and these lands cannot be used for the ultimate benefit of residents in rural communities. This is contrary to the experience in various African countries such as Tanzania, Botswana and Ghana.

Most of the rural poor in Ethiopia are smallholder farmers, and landlessness of the youth is becoming a serious problem. The daily income of the dwellers in the study area is less than USD 0.50. Hence, there is a strong nexus between communal lands and livelihood security for the rural poor in Hadiya Zone. Tenure security of communal land enables the rural poor to practice agricultural diversification such as livestock rearing. Mixed farming is indeed a way of life and cattle rearing or keeping small ruminants is a source of livelihood for the landless or rural poor.

In spite of these benefits of communal lands, encroachments on community lands are common as a result of government intrusions and illegal private appropriations. Government intrusions include appropriation to development projects and land allocation for different purposes. In case of private illegal appropriation, corruption facilitates the intrusions. As a result, tenure insecurity of communal lands adversely affects the livelihoods of the rural poor thereby eroding social security the economic welfare of the rural poor.

Land laws that subsume communal lands into the state-owned domain should be reexamined, in addition to which the definition of public purpose should be clearly restricted in such a manner that it shall not be abused in the guise of allocating land to 'investments' in economic activities. To this end, the local community should be given legal personality (as an entity) as in the case of other countries highlighted in the preceding sections. This facilitates the respect and fulfillment of the human rights of the rural poor in accordance with Ethiopia's obligations under its domestic laws and the international conventions it has ratified.

Moreover any decision that affects communal lands should involve the full and free consent of the people in the community. Communal lands should not be regarded as res nullius, and any allocation of land for various purposes should 
be based on empirical studies and impact assessment including its impact on the rural poor's livelihood. Such caution and prudence should apply to all forms of community land conversions including the relocation of community lands as a result of urban expansion. Decisions that relate to community lands should also consider and protect the spiritual and social aspect of communal lands. Actors in land transactions should be accountable. Void transactions like sale contracts of communal lands for development projects and other social affairs should be of no effect. Such measures towards nurturing and entrenching accountability can indeed start with the return of misappropriated communal lands to their legitimate holders. 